\title{
The level of aspiration as an indicator of a person's desire for financial well-being
}

\author{
Lidiya Berngardovna Shneyder ${ }^{1}$, Ilia Vladimirovich Egorov², and Polina Alexandrovna \\ Kozintseva ${ }^{3}$ \\ ${ }^{1}$ Moscow State University of Education, Institute of Childhood, Department of Psychological \\ Anthropology, Moscow, Russia \\ ${ }^{2}$ Moscow City University, Institute of Pedagogy and Psychology of Education, Psychology \\ Department, Moscow, Russia \\ ${ }^{3}$ Russian New University, Department of General and Labor Psychology, Moscow, Russia
}

\begin{abstract}
The mobility of the modern world generates interest not only in innovative technologies but also in workers themselves, the assessment of their level of aspiration. Consequently, the level of aspiration falls into the zone of research interest and should be considered as a significant factor of human practical activity. It can be studied through diagnostic procedures aimed at identifying the structural and content components free of the professional subject orientation. This corresponds to the study of the level of aspiration on the material of aspiration for financial well-being. The conducted empirical study explores the characteristics of the level of ambition including a focus on the goal, monetary motivation, professional preferences, assessment of personal resources and capabilities. The study sample consists of 42 budgetary workers at the average age of 35 . The overall direction and purpose of the empirical study are associated with revealing the characteristics of the level of ambition and its interrelation with Homo faber's desires and expectations, motivational and personal characteristics, value orientations, and focus on the goal. The primary research method is a written questionnaire (a survey). Goal orientations are found to be quite strongly expressed in the studied sample, the respondents have developed self-respect and are not inclined to shift the blame to external circumstances but lack ambition. It is revealed that a budgetary worker desires financial well-being and high income and does not mind getting rich but is not ready to change themselves and compromise the established norms of a stable life. The level of aspiration is found to be "split": the set objective goals are low compared to higher ones kept to oneself.
\end{abstract}

Keywords: working person, budgetary sphere, level of aspiration, financial well-being.

\section{Introduction}

An adult is included in three spheres of life: work, the family system, and the leisure space. In each of them, they claim something, strive to obtain something or achieve recognition. In

* Corresponding author: egorov_cpti@mail.ru 
the professional sphere, the aspiration to obtain something is reduced to achievements, financial income, benefits, constant demand, i.e., the aspirations are associated both with the work reality [1, 2] and the image of a successful happy person [3-6].

One can achieve a lot at work and receive plenty from it as well. An important role is played by the level of aspiration of an individual originally viewed as a manifestation of selfawareness, personal goals, and individual abilities [7-9]. The study of this phenomenon in Russian psychology was supplemented by the introduction of personality-assessment aspects [10-13]. The essence of the level of aspiration is now defined through the concept of "goal difficulty" that serves as a marker of the subject's goal-setting [11, 12, 14, 15]. Its level structure assumes the complication of intentions and the increase of efforts with each subsequent step $[1,16,17]$.

The level of aspiration is contingent on intellectual and volitional qualities, the manifestation of a person's neurodynamic characteristics, it is characterized by the degree of involvement in the social role and social and family life and is conditioned by professional affiliation, career orientations, and aspiration to domination $[2,12,18,19]$.

The overwhelming part of a person's aspirations is related to the expected status and monetary income. Financial well-being is an undoubted indicator of the life success of any person [20]. It strengthens the meaning component of life and is closely intertwined with the ideas of happiness and good luck [21-23].

Consequently, financial well-being can be considered an actual functioning predictor of the level of aspiration which is important for research practices, however, the relationship between these variables has been empirically understudied.

All of the above leads to the conception and design of the present empirical study as it is important to find answers to the following questions:

What role does the monetary motivation of a modern worker play in their aspiration? What are they willing to sacrifice for financial well-being? Does the level of aspiration depend on age, gender, health, and goal-setting? What promotes its growth and what inhibits it?

Answering these questions requires the diagnostic materials to be free from the subject orientation of a profession [24] and understandable and accessible to all study participants. This condition corresponds to the study of the level of aspiration on the material of a person's aspiration for financial well-being.

\section{$2 \quad$ Methods}

The empirical study involves a written questionnaire the core of which is a survey consisting of 32 items grouped into appropriate blocks: general information about the respondent; the level of aspiration in financial well-being; focus on the goal; monetary motivation; value orientations in work; the assessment of personal resources.

Study sample. A total of 42 people participated in the survey, all residents of Moscow and the Moscow region, of whom 38\% were men and $62 \%$ were women. The average age of the respondents was $35 \pm 2.1$ years old. The survey was conducted before the start of the COVID19 pandemic; at the time of the survey, all participants were employed in the public sector (education, healthcare, urban planning, etc.).

The goal of the study: to identify the characteristics of the level of aspiration of a person as an indicator of the desire for financial well-being.

Hypotheses of the study:

1) the level of aspiration of a working person and the variants of its manifestation are associated with gender, age, marital status, level of expectations, goal orientation, monetary motivation, value orientations in work, and personality resources; 
2) a low level of aspiration of a public sector employee is due to the desire for financial wellbeing on the one hand and the desire to preserve the stability of employment on the other.

\section{$3 \quad$ Results}

First of all, we explored the workers' real level of income and the desired income they focus on. Almost all of the respondents would like to increase their material income. The type of income was determined based on the difference between the desired and actual income. A high level of aspiration is demonstrated by $29 \%$ of the respondents, the average level is found in $33 \%$, and the low level is found in $38 \%$ of the study participants. In general, the sample can be characterized as unassuming.

$91 \%$ of the respondents have a life purpose. $98 \%$ of them report that they do achieve their goals. $24 \%$ of the survey participants believe that they have a worse life than they wanted and could live. Ambition and the desire to be the first in any matter are reported by $52 \%$ of the respondents. $88 \%$ of the respondents believe that if other people can achieve something in life, they can do it too. The presence of positive qualities and positive self-perception was self-reported by $86 \%$ of the participants. Thus, goal orientations in the sample under study are expressed quite strongly, the respondents have developed self-respect and are not inclined to shift the blame on circumstances and other people but lack ambition.

$60 \%$ of the respondents believe that they do not earn as much as they deserve, their level of aspiration is higher. $40 \%$ of the respondents are satisfied with their real earnings and find it fair. $52 \%$ of the respondents would like to have a lot of money whereas $48 \%$ would not. Neither of them would be tempted to work long hours even for the sake of wealth. $52 \%$ of the respondents agree to work a lot and $48 \%$ do not. Meanwhile, $69 \%$ of the respondents have the desire to become a millionaire if they do certain things within the law. $50 \%$ of the survey participants are ready to change themselves, their habits, and lifestyle to become a millionaire and the same percentage of the sample is not ready to do so. High monetary motivation is not present which supports the original hypothesis on the unpretentiousness of the group of studied respondents - employees of the budgetary sphere.

What the respondents value most about their work is ${ }^{\dagger}$

- the opportunity for self-expression $48 \%$

- the chance to be happy $40 \%$

- the ability to provide for children $40 \%$

- financial income $38 \%$

- the sense of self-esteem and recognition $36 \%$

- the opportunity to make other people happy $33 \%$

- inspiration $26 \%$

- career opportunities $24 \%$

As we can see, financial income is not of paramount importance and is not supported by the desire for career advancement.

Health problems are found in $33 \%$ of the respondents. Failure makes $62 \%$ of the participants more energetic in their pursuit of the goal. The habit of prolonged contemplation of how to take action is characteristic of $53 \%$ of respondents, the tendency to dominance is typical of $67 \%$ of the respondents, and proneness to risky behavior is found in $53 \%$ of the participants. Independence in decision-making is characteristic of $71 \%$ of respondents, orientation on calm and quiet life is typical of $60 \%$. Dependence on the opinion of other people is experienced by $55 \%$ of the respondents, preference of activity over inactivity is characteristic of $71 \%$, and ability to influence other people is found in $90 \%$ of the study

\footnotetext{
$\dagger$ The total exceeds $100 \%$ due to multiple choice.
} 
participants. Thus, most of the sample has a sufficient reserve of personal resources for professionalization. At least $60 \%$ of the respondents are healthy and energetic and have no special problems in overcoming obstacles.

\section{Discussion}

The relationship between the level of aspiration and other studied individual characteristics is tested using the Kendall tau rank correlation coefficient with the analysis of statistically significant $(\mathrm{p} \leq 0.01)$ but moderate ( $\tau \mathrm{b}$ ranges from a minimum value equal to 0.390 to a maximum value equal to 0.575 ) correlations.

Real income directly correlates with the desired income. In addition, the level of aspiration is directly related to focus on the goal and ambition but has no relationship to gender, age, or marital status.

Focus on the goal is associated with a personal predisposition to change and an orientation toward the desired income. Working for wealth requires personal transformation, a desire to dominate. It is prevented by an orientation toward a quiet, tranquil life (inverse correlation).

The obtained results indicate that readiness to become a millionaire and the desire for enrichment are far from being the same thing. Willingness to become a millionaire is associated with procedural analysis and reflection while the desire for money is related to a significant change in oneself. The desire for enrichment depends on the opinion of others and is reduced by a budgetary worker's invariable focus on a quiet, peaceful life. It also levels the example of other people's success. Ambition is "extinguished" by long reflection before starting an activity which has a negative effect on independence. An independent, autonomous worker makes decisions more easily and acts faster.

Factor analysis reveals 4 key components accounting for $76 \%$ of the cumulative variance. They are listed in descending order as follows.

1. Courageous requests and cautiousness associated with age and family. The working person is focused on monetary income, aspires to financial well-being, and realizes the need for change but is afraid of uncertainty, not ready for risks, and prefers to be cautious. Large incomes remain a tempting prospect but a person is not ready to work hard for their sake despite being aware of the need to provide for their family and children in a decent manner.

2. Inspiring contemplation of others' success. Other people's financial success is inspiring while simultaneously causing envy and regret over one's own financial situation. One's own desires do not produce much behavioral activity and coupled with much reflection, there is no intention to rebuild one's life in a better way. In the best case, the result is a transition to the zone of mortgage lending.

3. Underlying craving for wealth. The desire for a secure life does not leave a person but remains an irrational motive. The influence of intrapersonal conflict expressed in the socalled "split" levels of aspiration, i.e. in setting low objective goals compared to the higher ones kept to oneself [24].

4. Readiness for a spurt in action and the fear of it. Age, preserved health, and the desire for a better life intensify the initial readiness for changes in financial well-being but the fear of losing calmness and hasteless life block the impulses. Ambition, the feeling that one is capable of something more and deserves better, remains. Self-involvement is present but the level of aspiration is low and determines financial motivation poorly.

These components influence the situation of choice and resolving the tasks of increasing the monetary income of a working person which clarifies the internal mental-reflexive image of their low level of aspiration. 


\section{Conclusion}

Financial well-being plays an important role in the life of a modern person. The level of aspiration and the forms of its manifestation as an indicator of a working person's aspiration for financial well-being are determined by the discrepancy between the real and desired income.

A rather low level of real aspirations of a working person stems from the desire for financial well-being on the one hand and the desire to preserve the stability of their available wealth on the other. They are diligent, not too ambitious, not ready to change themselves, to compromise the principles of their habitual life, and they do not aspire to become a risk-taker.

\section{References}

1. A. A. Fediaev, Sootnoshenie urovnia pritiazanii, motivatsii dostizheniia i samootsenki na etape professionalnogo stanovleniia lichnosti [Correlation of the level of aspiration, achievement motivation, and self-esteem at the stage of the professional selfdetermination of a person]. Ph.D. dissertation in psychology (Saint Petersburg State University, Saint Petersburg, 2005)

2. A. I. Kulakova, Psikhologicheskie determinanty professionalnogo samoopredeleniia lichnosti [Psychological determinants of personal professional self-determination]: summary of a Ph.D. dissertation in psychology (Yaroslavl State University named after P.G. Demidov, Yaroslavl, 2018)

3. E. V. Zinko, Psikhologicheskii Zhurnal [Psychological Journal], 27(4), 15-26 (2006)

4. N. V. Rezanova, Uroven pritiazanii v sisteme lichnykh stremlenii: v kontekste integrativno-tselevogo podkhoda $\mathrm{k}$ lichnosti [The level of aspiration in the system of personal aspirations: in the context of the integrative-goal approach to personality]: Ph.D. dissertation in psychology (Far Eastern State Transport University, Khabarovsk, 2007)

5. P. M. Shamionov, Mir Psikhologii [World of Psychology], 2, 143-148 (2012)

6. J. Collins, Ot khoroshego k velikomu [Good to Great] (Mann, Ivanov \& Ferber, Moscow, 2017)

7. J. Frank, American Journal Psychology, 7, 119-128 (1935)

8. A. Gilinsky, Journal Exp. Psychol, 39(2), 256-259 (1949)

9. K. Lewin, T. Dembo, L. Festinger, P. Sears, Level of aspiration, in J. Hunt (ed.), Personality and the behavior disorders, Vol. 1, 333-379 (The Ronald Press Company, New York, 1944)

10. B.V. Zeigarnik, V.V. Nikolaeva, L.B. Filonov, Issledovanie urovnia pritiazanii [The study of the level of aspiration], in A.N. Leontiev, Iu.B. Gippenreiter (Ed.), Praktikum po psikhologii, 216-219 (Moscow State University publishing house, Moscow, 1972)

11. T. A. Kuzmin, Russian Scientific Journal, 4(5), 120-126 (2008)

12. L.V. Borozdina, Uroven pritiazanii: klassicheskie i sovremennye issledovaniia [Level of aspiration: classical and modern studies] (Akropol, Moscow, 2011)

13. K.R. Sidorov, Bulletin of Udmurt University, Philosophy. Psychology. Pedagogy, 2 , 40-49 (2014)

14. J. Nuttin, Protsess formirovaniia tseli [The process of goal-setting], in V.V. Petukhov (Ed.), Obshchaia psikhologiia. Subekt deiatelnosti, Vol. 2, Book 2, 239-244 (Educational and Methodological Collector "Psikhologiia"; Moscow Psychological and Social Institute, Moscow, 2004) 
15. D.A. Leontiev, D.D. Suchkov, Psikhologicheskie Issledovaniia [Psychological Research], 8(44), 1 (2015)

16. N.A. Baturin, Bulletin of the South Ural State University. Series "Psychology", 11(3), 5-12 (2018)

17. O.P. Krolevets, Sotsialnye predstavleniia o neuspeshnom cheloveke i psikhologicheskie prediktory professionalnogo neuspekha [Social perceptions of an unsuccessful person and psychological predictors of professional unsuccess], Summary of a Ph.D. dissertation in psychology (Omsk State University named after F.M.

Dostoyevsky, Omsk, 2018)

18. H. Heckhausen, Psikhologiia motivatsii dostizheniia [The Psychology of Achievement Motivation] (Rech, Saint Petersburg, 2001)

19. T. Peters, Predstavte sebe! Prevoskhodstvo v biznese v epokhu razrushenii [ReImagine! Business Excellence in a Disruptive Age] (Stockholm School of Economics Russia, Saint Petersburg, 2005)

20. E. I. Gorbacheva, A. B. Kupreichenko, Psikhologicheskii Zhurnal [Psychological Journal], 27(4), 26-38 (2006)

21. A. Laengle, Scientific Notes Journal of St. Petersburg State Institute of Psychology and Social Work, 23(1), 7-15 (2015)

22. M. Seligman, Put k protsvetaniiu: novoe ponimanie schastia i blagopoluchiia [The Path to Prosperity: A New Understanding of Happiness and Well-Being] (Mann, Ivanov \& Ferber, Moscow, 2013)

23. H. Klug, G. Maier, Journal of Happiness Studies, 16(1), 37-65 (2015) https://doi.org/10.1007/s10902-013-9493-0

24. N.A. Baturin, N.A. Kurganskii, Uroven pritiazanii kak metod issledovaniia lichnosti [Level of aspiration as a method for the study of personality], in F.I. Sluchevskiy (Ed.), Diagnostika psikhicheskikh sostoianii v norme i patologii [Diagnostics of mental states in health and disease], 140-148 (Medicina, Leningrad, 1980) 